\title{
Chuva das Perseidas
}

\author{
Margarida Maria Knobbe
}

Mágicas estrelas, irmãs de poeira, visitam meus olhos, rápidas, e convidam a dançar no espaço de Copérnico, Galilei, Kepler, Newton, Einstein, Hubble e Sagan.

Tridimensão

de surpresas distantes.

Perseidas! Perseidas!

Uau!

Chuveiro de luz

que inunda o coração.

Um céu para recordar:

uma a uma,

centenas de estrelas-meteoro

iluminam em linha de flashes

a minha imaginação.

Universo sou.

Margarida Maria Knobbe é professora da Estácio Natal, mestre e doutora em Ciências Sociais pela UFRN, pesquisadora do GRECOM - Grupo de Estudos da Complexidade da UFRN. 